\title{
The impacts of recent drought on fire, forest loss, and regional smoke emissions in lowland Bolivia
}

\author{
Joshua P. Heyer ${ }^{1}$, Mitchell J. Power ${ }^{1,2}$, Robert D. Field ${ }^{3,4}$, and Margreet J. E. van Marle ${ }^{5,6}$ \\ ${ }^{1}$ Geography Department, University of Utah, Salt Lake City, UT 84112-9155, USA \\ ${ }^{2}$ Natural History Museum of Utah, University of Utah, Salt Lake City, UT 84112, USA \\ ${ }^{3}$ NASA Goddard Institute for Space Studies, New York, NY 10025, USA \\ ${ }^{4}$ Department of Applied Physics and Applied Mathematics, Columbia University, New York, NY 10025, USA \\ ${ }^{5}$ Faculty of Earth and Life Sciences, Vrije Universiteit Amsterdam, Amsterdam, the Netherlands \\ ${ }^{6}$ Deltares, Delft, the Netherlands
}

Correspondence: Joshua P. Heyer (josh.heyer@geog.utah.edu)

Received: 30 October 2017 - Discussion started: 1 February 2018

Revised: 26 June 2018 - Accepted: 3 July 2018 - Published: 17 July 2018

\begin{abstract}
In the southern Amazon relationships have been established among drought, human activities that cause forest loss, fire, and smoke emissions. We explore the impacts of recent drought on fire, forest loss, and atmospheric visibility in lowland Bolivia. To assess human influence on fire, we consider climate, fire, and vegetation dynamics in an area largely excluded from human activities since 1979, Noel Kempff Mercado National Park (NK) in northeastern Bolivia. We use data from five sources: the Moderate Resolution Imaging Spectroradiometer Collection 6 active fire product (2001-2015) (MODIS C6), Global Fire WEather Database (GFWED) data (1982-2015), MODIS land cover data (2001-2010), MODIS forest loss data (2000-2012), and the regional extinction coefficient for the southwestern Amazon (i.e., $B_{\text {ext }}$ ), which is derived from horizontal visibility data from surface stations at the World Meteorological Organization (WMO) level (1973-2015). The $B_{\text {ext }}$ is affected by smoke and acts as a proxy for visibility and regional fire emissions. In lowland Bolivia from 2001 to 2015, interannual Drought Code (DC) variability was linked to fire activity, while from 1982 to 2015, interannual DC variability was linked to $B_{\text {ext }}$. From 2001 to 2015 , the $B_{\text {ext }}$ and MODIS C6 active fire data for lowland Bolivia captured fire seasonality, and covaried between low- and high-fire years. Consistent with previous studies, our results suggest $B_{\text {ext }}$ can be used as a longer-term proxy of regional fire emissions in southwestern Amazonia. Overall, our study found drought conditions were the dominant control on interannual fire variability in
\end{abstract}

lowland Bolivia, and fires within NK were limited to the Cerrado and seasonally inundated wetland biomes. Our results suggest lowland Bolivian tropical forests were susceptible to human activities that may have amplified fire during drought. Human activities and drought need to be considered in future projections of southern Amazonian fire, in regard to carbon emissions and global climate.

\section{Introduction}

Observations from the southern Amazon reveal fire emissions increased from 1987 through the early 2000s (van Marle et al., 2017). During this time, humans used fire in the southern Amazon while logging timber, and to clear land for building infrastructure and agriculture (Moran, 1993; Nepstad et al., 1999, 2009; Fearnside, 2005; Morton et al., 2008; Cochrane and Barber, 2009; van der Werf et al., 2010), suggesting human activities had a significant impact on increased smoke emissions from fire (van Marle et al., 2017). To minimize the impacts of deforestation and fire on deforestation in the Amazon, and in turn on carbon emissions and global climate, restrictions on land expansion and policies regulating beef and soy production in the Brazilian Amazon were implemented during the early 2000s (Nepstad et al., 2014). While these restrictions and policy changes helped reduce deforestation from 2004 to 2013 (Nepstad et al., 2014), others suggest a decrease in demand for Amazon resources 
was the primary driver of reduced deforestation and fire from 2004 to 2012 (Fearnside, 2017). Outside of the Brazilian Amazon, forest loss from deforestation and fire has continued in parts of the southern Amazon, particularly in lowland Bolivia (Chen et al., 2013b; van Marle et al., 2016, 2017). The Cerrado biome in particular has experienced increased deforestation since 2010, which could be due to a shift in agriculture to the southern Amazon and Cerrado (SoaresFilho et al., 2014). Likely amplifying the effects of deforestation and fire on forest loss in the southern Amazon were drought conditions during the early 2000s (Brown et al., 2006; Aragão et al., 2007; Marengo et al., 2008), raising the question of what the relationships among recent drought, fire, and forest loss in lowland Bolivia are.

Both paleofire investigations (Bush et al., 2008; Marlon et al., 2008; Power et al., 2013) and modern fire records (Brown et al., 2006; Aragão et al., 2007; Marengo et al., 2008) link drought to fire in the southern Amazon. Our study considers relationships between recent drought and fire in lowland Bolivia using the Global Fire WEather Database (GFWED) (Field et al., 2015) and the Moderate Resolution Imaging Spectroradiometer Collection 6 (MODIS C6) active fire product (Giglio et al., 2016). The GFWED Drought Code (DC) in particular captures net drying of deep fuels, with lower DC values observed during the wet season and higher DC values during the dry season (Field et al., 2015). We interpret high (low) DC values during the fire season from August to October in lowland Bolivia as an indicator of antecedent dry (wet) conditions during the preceding wet and dry seasons.

In addition to understanding links between drought and fire in lowland Bolivia, we also consider where past fires occurred spatially in relation to land use and biome type using data from the MODIS-based global land cover product (Broxton et al., 2014) and the Landsat-based forest loss product (Hansen et al., 2013). Considering humans have had a significant impact on forest loss and fire activity in unprotected biomes (Morton et al., 2013), we compare fire distribution in unprotected biomes in lowland Bolivia to biomes in Noel Kempff Mercado National Park (NK), an area in lowland Bolivia protected from deforestation since 1979. Specifically, we explore climate and fire relationships in NK to determine when fire activity is high in relation to interannual climate variability, and where fire occurs spatially in relation to different biomes and land uses.

Finally, to extend our fire record for lowland Bolivia prior to the onset of MODIS C6 in 2001, we analyze horizontal visibility data from surface weather stations at the World Meteorological Organization (WMO) level. Visibility data have been used as a fire emissions proxy to understand fire activity over the southern Amazon from 1973 to 2015 (van Marle et al., 2017). We test relationships between MODIS C6 active fire data for lowland Bolivia and regional WMO visibility data (locations of weather stations in Fig. 1a), to determine how well visibility data correspond to the MODIS C6 fire record from 2001 to 2015 and to extend the fire record for lowland Bolivia prior to 2001.

Our results are useful and relevant when considering uncertainties regarding the fate of the southern Amazon in response to climate change (Zhang et al., 2015). Here, we show how recent interannual climate variability has impacted fire activity across different biomes in lowland Bolivia. A further understanding of relationships among interannual climate variability and biome type and fire in lowland Bolivia is valuable when considering fire weather (Bedia et al., 2015) and fire season severity are expected to increase in the southern Amazon during the 21st century (Flannigan et al., 2013). Further, fire in the southern Amazon can cause increased smoke emissions that negatively impact human health (e.g., Brown et al., 2006), and can impact carbon emissions and global climate (Fearnside, 2005; Aragão et al., 2014). Seasonal covariation between fire and horizontal visibility data are explored here to provide further information on how fire is related to visibility and smoke emissions in the southern Amazon.

\section{Methods and data}

\subsection{MODIS C6 and Landsat data}

MODIS C6 offers a tool to adequately answer questions related to recent fire activity from November 2000 to present (Morton et al., 2011). MODIS C6 has been used globally to explore a variety of fire-related questions ranging from biomass burning (Wooster et al., 2003) to fire detection in the Amazon (Chen et al., 2013a). High-spatial-resolution (1 km) near-real-time MODIS C6 data used in our analyses are provided by the Land, Atmosphere Near real-time Capability for Earth Observing System Fire Information for Resource Management System, and are operated by the NASA Goddard Space Flight Center Earth Science Data and Information System (Giglio et al., 2016). Two key limitations of the previous MODIS C5 product were small forest clearings causing false active fires, and thick smoke obscuring large fires (Giglio et al., 2016). For tropical ecosystems, these two key limitations were addressed and errors were reduced from MODIS C5 to MODIS C6 (Giglio et al., 2016).

For our study, MODIS C6 data for Bolivia (Fig. 1b) were downloaded using the NASA Earth Observation Data archive download tool. Data were subset by location (e.g., NK), year, and by fire detection confidence $\geq 90 \%$. Only active fire points $\geq 90 \%$ were included in our analyses to further reduce the potential for false active fires. MODIS C6 data seen in Brazil are shown in spatial analyses (i.e., Figs. 4 and 5), but were not used in statistical analyses (Tables 1, 2, 3).

Landsat forest loss data 2000-2012 (Hansen et al., 2013) and MODIS-based Collection 5.1 MCD12Q global land cover data (Broxton et al., 2014) were obtained to determine the spatial coherency of fire, land use, and forest loss. 
(a) MODIS Smoke August 17th, 2010

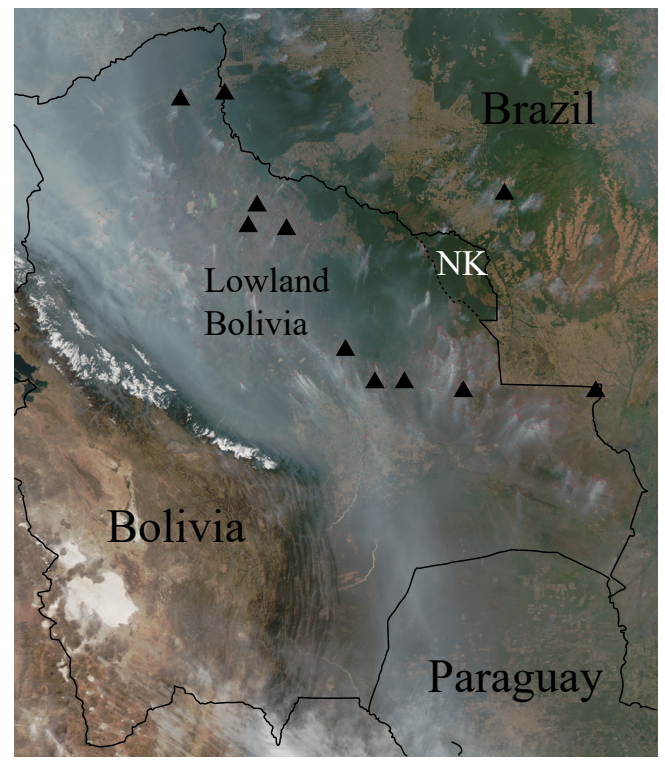

(b) MODIS C6 Acitve Fires: 2001-2015

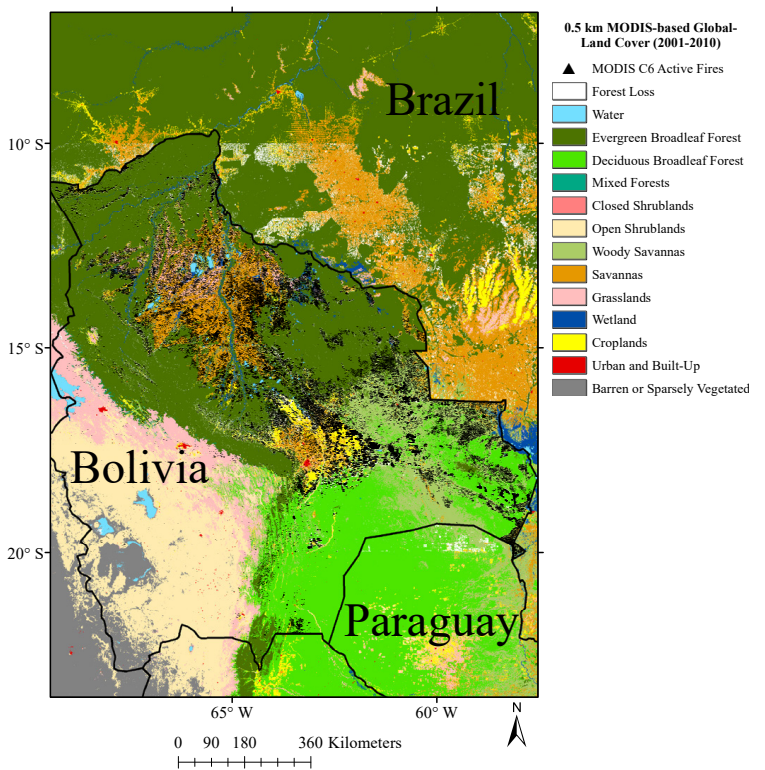

Figure 1. Fires and smoke observed by the Moderate Resolution Imaging Spectroradiometer (MODIS) over Bolivia and Noel Kempff Mercado National Park (NK) on 17 August 2010 (a), the highest fire year observed by the MODIS active fire product for Bolivia during the record (2001-2015). The locations of the 11 World Meteorological Organization (WMO) surface stations used to obtain visibility data are shown as black triangles (a). NASA image courtesy of Jeff Schmaltz. Forest loss from 2000 to 2012 (Hansen et al., 2013) displayed in white (b), and Moderate Resolution Imaging Spectroradiometer C6 (MODIS C6) active fires with $\geq 90 \%$ confidence from 2001 to 2015 displayed as black triangles (b). MODIS-based Collection 5.1 MCD12Q global land cover data (Broxton et al., 2014) are included (b).

High-spatial-resolution figures (i.e., Figs. 1, 4, 5) were created for detailed spatial analyses. Considering the high spatial resolution of certain figures, to view forest loss displayed as white pixels (i.e., Fig. 5), or detailed biome and fire spatial variability (e.g., Fig. 1), readers will need to increase the zoom. To simplify in-text discussions on the spatial distribution of fire in lowland Bolivia in relation to various biomes, MODIS land cover types seen in figure legends (i.e., Figs. 1b, 4, 5) will be hereafter referred to in the paper as the Cerrado, METF, SDTF, and seasonally inundated wetlands. The Cerrado biome includes open shrubland, woody savanna, savanna, and grassland MODIS land cover types. The SDTF biome includes deciduous broadleaf forest, mixed forest, and closed shrubland MODIS land cover types. The METF biome includes the evergreen broadleaf forest MODIS land cover type. Seasonally flooded wetlands in lowland Bolivia are hydromorphic climatic savannas that are periodically flooded during the wet season and desiccate during the dry season (Junk et al., 2011). For readers interested in a more detailed land cover classification (Broxton et al., 2014), the original land classification was maintained in some figures (i.e., Figs. 1b, 4, 5) for detailed spatial analyses of fires and biomes over lowland Bolivia.

\subsection{Horizontal extinction coefficient calculated from visibility observations}

In the absence of long-term fire data, horizontal visibility has been used as a proxy for fire emissions in Indonesia (Field et al., 2009, 2016) and Amazonia (van Marle et al., 2017). Here, horizontal visibility observations (1973-2015) were taken from the NOAA National Climatic Data Center Integrated Surface Database (https://catalog.data.gov/dataset/ integrated-surface-global-hourly-data, last access: February 2017), which is comprised of data from WMO-level surface stations provided by national meteorological agencies. Horizontal visibility observations are human-made using landmarks with known distances during the day and using point light sources at night (World Meteorological Organization, 1996). Horizontal visibility is influenced by several sources including dust, air pollution, haze, fog, and precipitation. Fires also have a strong impact on visibility, and are therefore used here as a proxy of regional fire emissions in lowland Bolivia.

To correct for limitations of the human eye and imperfections of the landmarks used to estimate the maximum distance seen, the observations in meters are usually expressed as the extinction coefficient $\left(B_{\text {ext }}, \mathrm{km}^{-1}\right)$. In our case, $B_{\text {ext }}$ corresponds to the degree to which light is attenuated by scattering and extinction over a horizontal path. A total of 
Table 1. Mean monthly Pearson's correlations (January 2001-December 2015) between Moderate Resolution Imaging Spectroradiometer C6 (MODIS C6) active fires with $\geq 90 \%$ confidence and Global Fire WEather Database (GFWED) variables for Bolivia (i.e., table columns 1-2) and NK (i.e., table columns 3-4). All correlation $p$ values were $<0.001$ with 178 degrees of freedom, unless otherwise noted (e.g., NK MODIS and MERRA-2 precipitation: $p$ value $=0.003$ ). Correlations are listed in order of strongest (i.e., top row) to weakest (i.e., bottom row).

\begin{tabular}{|c|c|c|c|}
\hline Bolivia & $\begin{array}{r}95 \% \text { confidence } \\
\text { interval }\end{array}$ & NK & $\begin{array}{r}95 \% \text { confidence } \\
\text { interval }\end{array}$ \\
\hline Bolivia MODIS \& GPCP DC & 0.69 to 0.82 & NK MODIS \& TRMM DC & 0.39 to 0.61 \\
\hline Bolivia MODIS \& TRMM DC & 0.68 to 0.81 & NK MODIS \& GPCP DC & 0.38 to 0.60 \\
\hline Bolivia MODIS \& CPC DC & 0.65 to 0.79 & NK MODIS \& CPC DC & 0.33 to 0.56 \\
\hline Bolivia MODIS \& MERRA-2 DC & 0.58 to 0.74 & NK MODIS \& MERRA-2 DC & 0.28 to 0.53 \\
\hline $\begin{array}{l}\text { Bolivia MODIS \& MERRA-2 relative } \\
\text { humidity }\end{array}$ & -0.56 to -0.73 & NK MODIS \& MERRA-2 temperature & 0.24 to 0.49 \\
\hline $\begin{array}{l}\text { Bolivia MODIS \& MERRA-2 } \\
\text { temperature }\end{array}$ & 0.43 to 0.64 & NK MODIS \& MERRA-2 relative humidity & -0.21 to -0.47 \\
\hline $\begin{array}{l}\text { Bolivia MODIS \& MERRA-2 } \\
\text { precipitation }\end{array}$ & -0.27 to -0.51 & $\begin{array}{l}\text { NK MODIS \& MERRA-2 precipitation } \\
\left({ }^{*} p \text { value }=0.003\right)\end{array}$ & -0.07 to -0.35 \\
\hline Bolivia MODIS \& GPCP precipitation & -0.25 to -0.50 & $\begin{array}{l}\text { NK MODIS \& GPCP precipitation } \\
\left({ }^{*} p \text { value }=0.004\right)\end{array}$ & -0.07 to -0.35 \\
\hline Bolivia MODIS \& TRMM precipitation & -0.24 to -0.50 & $\begin{array}{l}\text { NK MODIS \& TRMM precipitation } \\
\left({ }^{*} p \text { value }=0.004\right)\end{array}$ & -0.06 to -0.34 \\
\hline Bolivia MODIS \& CPC precipitation & -0.24 to -0.49 & $\begin{array}{l}\text { NK MODIS \& CPC precipitation } \\
\left({ }^{*} p \text { value }=0.01\right)\end{array}$ & -0.05 to -0.33 \\
\hline
\end{tabular}

11 stations were selected and the monthly median $B_{\text {ext }}$ over these selected stations was found to be representative for fire emissions over the region $\left(7-17^{\circ} \mathrm{S}, 58-68^{\circ} \mathrm{W}\right)$ (Fig. 1a). We only used individual observations taken at 12:00 UTC (corresponding to 08:00 local time), as the frequency of reports at other times varied considerably during the length of record. The data were subsequently filtered following Husar et al. (2000) and van Marle et al. (2017) to omit observation influence by fog or precipitation, and aggregated to monthly values.

\subsection{Global Fire WEather Database (GFWED)}

To examine climatic controls on fires in NK, we used meteorological parameters and components of the Fire Weather Index (FWI) system, which integrates different surface weather parameters influencing the likelihood of fires starting and spreading. The FWI system consists of moisture codes for three generalized fuel classes and three fire behavior components, computed each day from surface temperature, relative humidity (RH), wind speed, and precipitation. Because of its flexibility, it is the most widely used of such systems in the world and has been adapted for use in different fire environments operationally and for research purposes (de Groot and Flannigan, 2014).

To explore interannual climate variability related to fire activity in lowland Bolivia, FWI data for the period 1982-2015, were obtained from the GFWED (Field et al., 2015) and processed for a $50 \mathrm{~km} \times 50 \mathrm{~km}$ bounding box over NK (13$15.3^{\circ} \mathrm{S}, 62.2-59.5^{\circ} \mathrm{W}$ ), and for a bounding box over low- land Bolivia. The GFWED, gridded to a $0.5^{\circ}$ latitude $\times 2 / 3^{\circ}$ longitude resolution, includes different versions that are all computed using daily to hourly temperature, $\mathrm{RH}$, and wind speed from the NASA MERRA-2 reanalysis (Gelaro et al., 2017), but using different estimates of daily precipitation, which is the most uncertain input to the FWI system, particularly in the tropics (Field et al., 2015). From these, we use in our analyses monthly averages of the DC, precipitation $\left(\mathrm{mm} \mathrm{day}^{-1}\right)$, temperature $\left({ }^{\circ} \mathrm{C}\right)$, and $\mathrm{RH}(\%)$. The DC is an indicator of seasonal drying (Field et al., 2015), and is the simplest of the six FWI components. DC values that exceed 425 are considered extreme (Field et al., 2015). Precipitation, temperature, and RH were included to compare the explanatory power of basic surface weather variables compared to the DC. For the DC and precipitation, we used versions computed from the "raw" MERRA-2 precipitation estimate and a MERRA-2 rain-gauge-corrected version used in the MERRA-2 land surface scheme to provide a measure of the dependence of our results on uncertainty in the precipitation estimates. Additional precipitation data were obtained from the Climate Prediction Center (CPC), the Global Precipitation Climatology Project (GPCP), and the Tropical Rainfall Measuring Mission (TRMM). The CPC estimates precipitation from rain gauge data at $0.5^{\circ} \times 0.5^{\circ}$ resolution (Chen et al., 2008), the GPCP estimated precipitation from satellites at $2.5^{\circ} \times 2.5^{\circ}$ resolution (Huffman et al., 2009), and the TRMM estimated precipitation from satellites at $0.25^{\circ} \times 0.25^{\circ}$ resolution (Huffman et al., 2007). For each GFWED variable, mean monthly time series were constructed for Bolivia and NK from January 2001 to December 2015, and from Jan- 
(a)

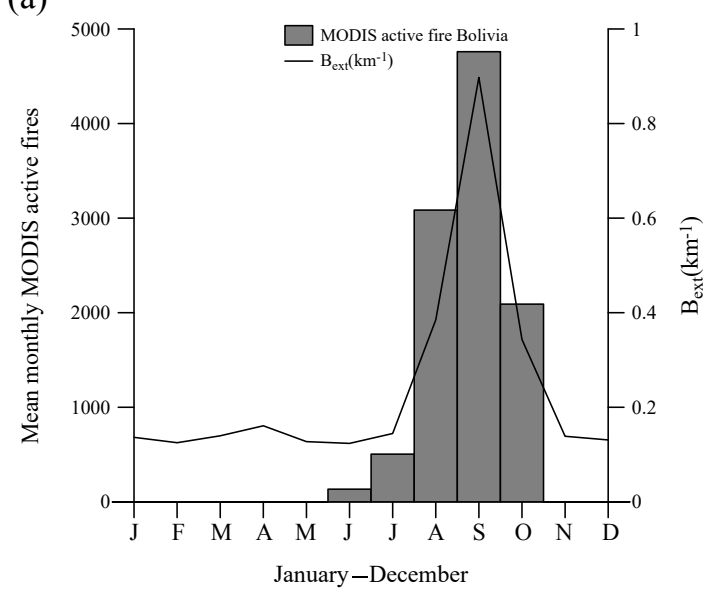

(b)

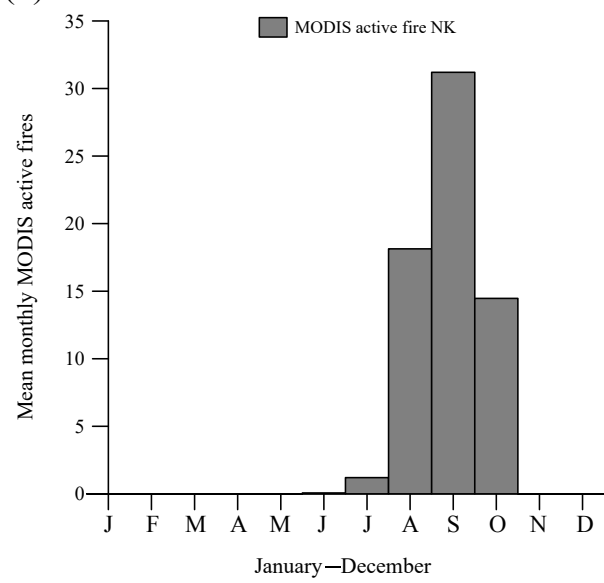

Figure 2. Mean monthly Moderate Resolution Imaging Spectroradiometer C6 (MODIS C6) active fires with $\geq 90 \%$ confidence (20012015) for Bolivia (a) and Noel Kempff Mercado National Park (NK) (b). Mean monthly extinction coefficient $B_{\text {ext }}\left(\mathrm{km}^{-1}\right.$ ) (1973-2015) is included for Bolivia (a). Fire seasonality is clearly demonstrated for both Bolivia (a) and NK (b) (e.g., peak fire from August to October). For Bolivia, $85 \%$ of fires were detected from August to October (MODIS C6 active fire with $\geq 90 \%$ confidence). For NK, $96 \%$ of fires were detected from August to October (MODIS C6 active fire with $\geq 90 \%$ confidence). From 2001 to 2015, a $95 \%$ correlation confidence interval of 0.76-0.86 was observed between mean monthly $B_{\text {ext }}\left(\mathrm{km}^{-1}\right)$ and monthly lowland Bolivia MODIS C6 active fires (a).

uary 1982 to December 2015. Mean fire season (AugustOctober) time series were also created for selected GFWED variables from August 1982 to October 2015.

\subsection{Statistical analyses}

Several sets of linear correlations were performed in $\mathrm{R}$ to better understand seasonal and interannual relationships among MODIS C6, GFWED, and WMO visibility data. For each set of correlations, correlation coefficients were estimated using a Pearson's coefficient, with a standard transformation to a $t$ statistic to assess significance (e.g., alpha level: $0.05)$. First, to demonstrate seasonal covariation between fire and visibility, correlations were performed among monthly MODIS C6 data (i.e., total monthly fires) for lowland Bolivia and mean monthly WMO visibility (i.e., mean monthly $B_{\text {ext }}$ ) data. Next, to provide information on seasonal relationships, correlations were performed between monthly MODIS C6 data (i.e., total monthly fires) and mean monthly GFWED data, as well as between mean monthly WMO visibility data and mean monthly GFWED data, both for the period January 2001-December 2015. Finally, to better understand interannual relationships, correlations for lowland Bolivia were performed between mean fire season (i.e., August-October) GFWED data and mean fire season WMO visibility (i.e., mean monthly $B_{\text {ext }}$ ) data from 1982 to 2015 . In addition to Pearson's correlations, MODIS C6 fire climatologies were calculated for lowland Bolivia and NK for the time period 2001-2015 to identify higher-than-normal fire years. WMO visibility (i.e., mean monthly $B_{\text {ext }}$ ) climatology was calculated for lowland Bolivia for the time period 1983-2015 to further demonstrate seasonal covariation between fire and $B_{\text {ext }}$ seasonality over lowland Bolivia.

\section{Results}

\subsection{Fire spatial distribution and seasonality in lowland Bolivia and NK (2001-2015)}

The spatial distribution of MODIS C6 active fires in lowland Bolivia and NK is seen from 2001 to 2015 (Fig. 1b). For lowland Bolivia from 2001 to 2015, a significant relationship was found between mean monthly MODIS C6 fire data and $B_{\text {ext }}$ data, with a $95 \%$ correlation confidence interval of $0.76-0.86$. During this time $85 \%$ of mean monthly MODIS C6 fires were from August to October, with an average of 10574 fires $^{-1} \mathrm{r}^{-1}$ (Fig. 2a). Both MODIS C6 fire seasonality and peak $B_{\text {ext }}$ occurred from August to October, demonstrating seasonal covariation. For NK from January 2001 to December 2015, $96 \%$ of mean monthly MODIS C6 fires were from August to October, with an average of 65 fires $\mathrm{yr}^{-1}$ (Fig. 2b).

\subsection{Climate and fire relationships in lowland Bolivia}

For lowland Bolivia from 2001 to 2015, higher-than-normal (i.e., $>10574$ fires $\mathrm{yr}^{-1}$ ) MODIS C6 fire years were identified in 2004, 2005, 2007, 2008, 2010, and 2011 (Fig. 3a). Relationships among Bolivia monthly MODIS C6 fire data and mean monthly GFWED precipitation (Fig. 3b) and temperature (Fig. 3d) variables were weaker than relationships among Bolivia monthly MODIS C6 fire data and mean 
Bolivia: 2001-2015

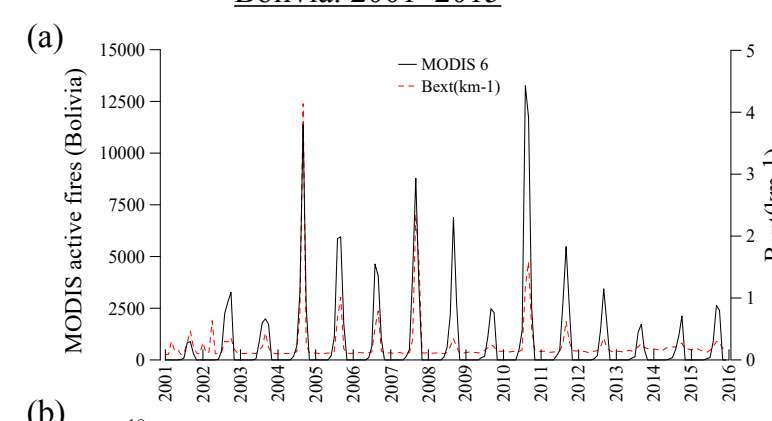

(b)

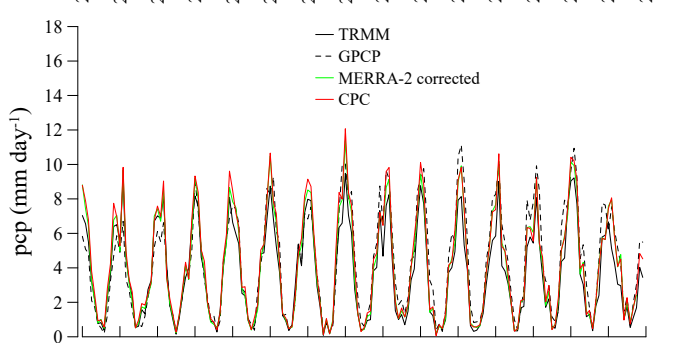

(c)

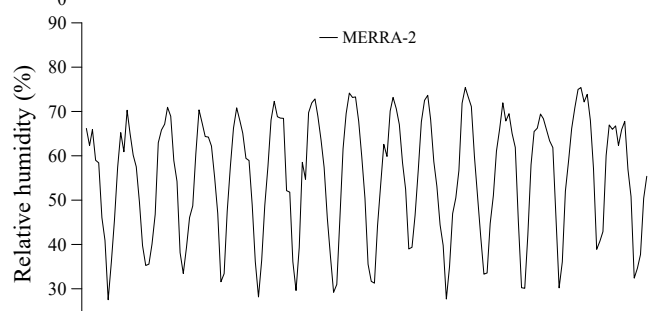

(d)

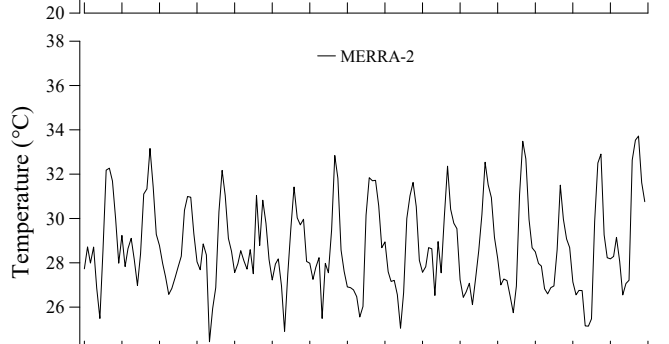

(e)
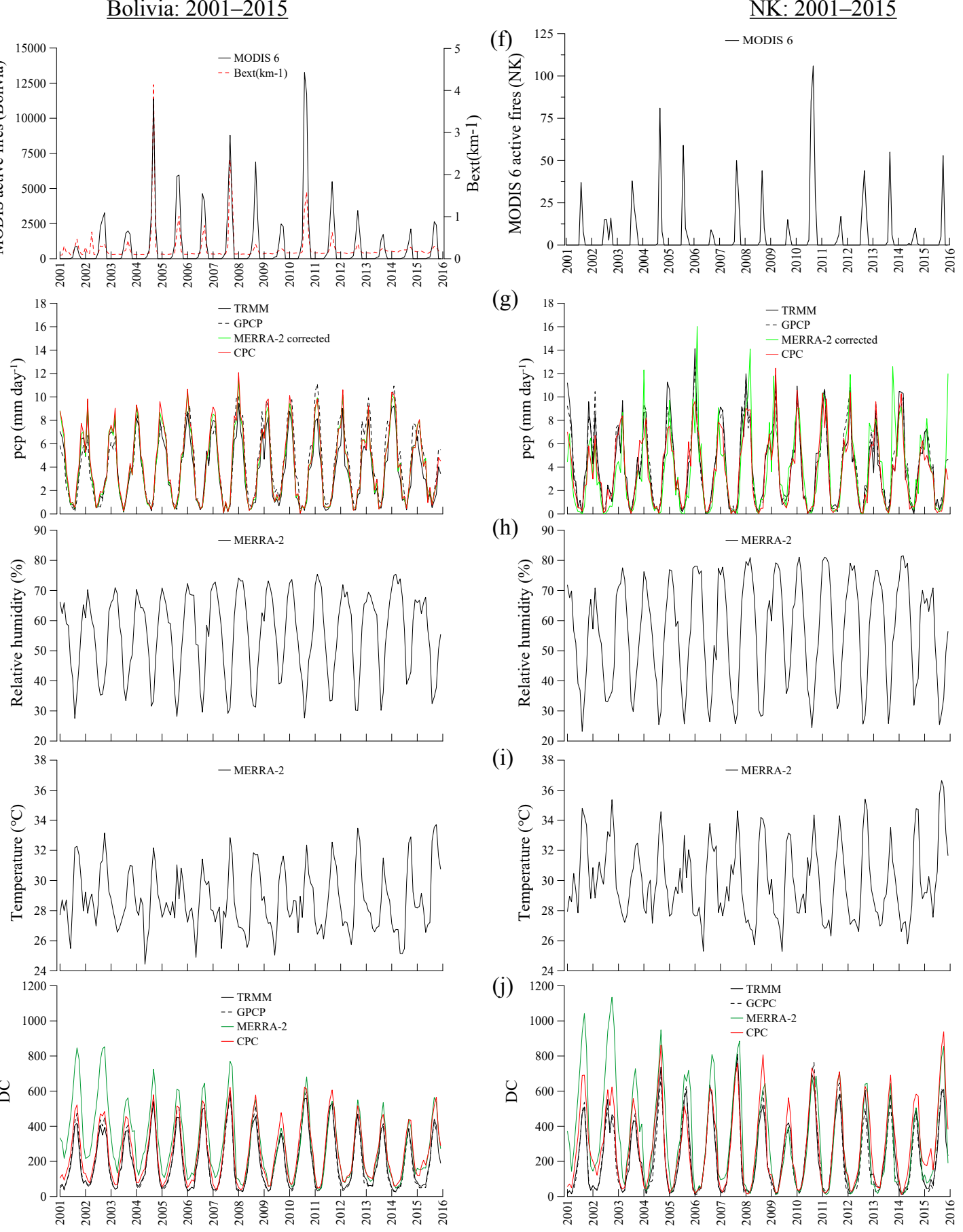

(g)

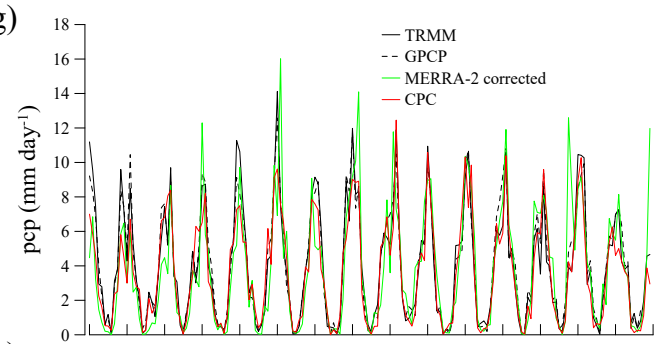

(h)

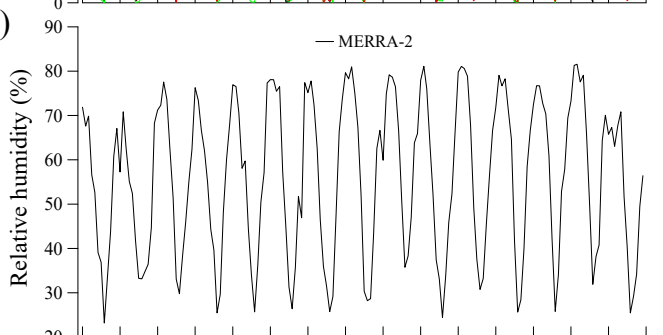

(i)

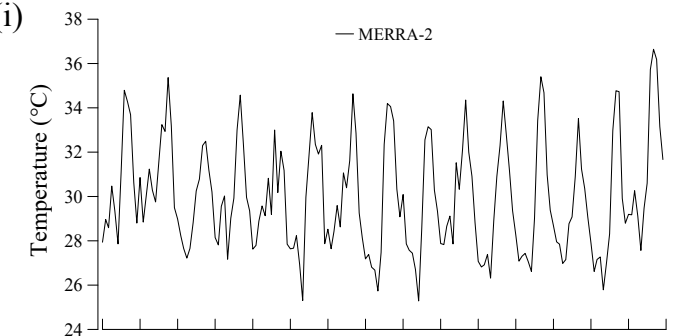

(j)

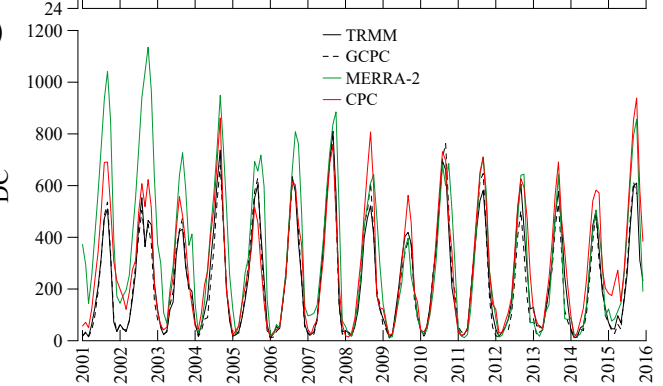

Figure 3. Mean monthly (January-December) time series of MODIS C6 active fires (a, f), of the extinction coefficient $B_{\text {ext }}(\mathbf{a})$, and of selected Global Fire WEather Database (GFWED) variables (b, $\mathbf{c}, \mathbf{d}, \mathbf{e}, \mathbf{g}, \mathbf{h}, \mathbf{i}, \mathbf{j})$. Time series are for Bolivia (a-e) and NK (f-j) from 2001 to 2015. GFWED variables include precipitation from four sources $(\mathbf{b}, \mathbf{g})$, MERRA-2 relative humidity (c, h), MERRA-2 temperature (d, i), and the Drought Code (DC) calculated from four sources $(\mathbf{e}, \mathbf{j})$. 
Table 2. Mean monthly Pearson's correlations (January 2001-December 2015) between $B_{\text {ext }}\left(\mathrm{km}^{-1}\right)$ and Global Fire WEather Database (GFWED) variables for Bolivia (i.e., table columns 1-2), compared to the same Pearson's correlations over the entire GFWED record from January 1982 to December 2015 (i.e., table columns 3-4). All correlation $p$ values were $<0.001$, unless otherwise noted (e.g., $B_{\text {ext }}\left(\mathrm{km}^{-1}\right)$ and MERRA-2 precipitation: ${ }^{*} p$ value $=0.0013$ ). Bolivia (January 2001-December 2015) correlations have 178 degrees of freedom, and Bolivia (January 1982-December 2015) correlations have 406 degrees of freedom. Correlations (i.e., table columns 1-2) are listed in order of strongest (i.e., top row) to weakest (i.e., bottom row).

\begin{tabular}{|c|c|c|c|}
\hline Bolivia (Jan 2001-Dec 2015) & $\begin{array}{r}95 \% \text { confidence } \\
\text { interval }\end{array}$ & Bolivia (Jan 1982-Dec 2015) & $\begin{array}{r}95 \% \text { confidence } \\
\text { interval }\end{array}$ \\
\hline$B_{\text {ext }}\left(\mathrm{km}^{-1}\right) \&$ TRMM DC & 0.38 to 0.60 & NA & NA \\
\hline$B_{\text {ext }}\left(\mathrm{km}^{-1}\right) \&$ GPCP DC & 0.37 to 0.60 & NA & NA \\
\hline$B_{\text {ext }}\left(\mathrm{km}^{-1}\right) \&$ CPC DC & 0.34 to 0.57 & $B_{\text {ext }}\left(\mathrm{km}^{-1}\right) \&$ CPC DC & 0.45 to 0.59 \\
\hline$B_{\text {ext }}\left(\mathrm{km}^{-1}\right) \&$ MERRA-2 DC & 0.33 to 0.56 & $B_{\text {ext }}\left(\mathrm{km}^{-1}\right) \&$ MERRA-2 DC & 0.36 to 0.52 \\
\hline$B_{\text {ext }}\left(\mathrm{km}^{-1}\right) \&$ MERRA-2 relative humidity & -0.24 to -0.49 & $B_{\text {ext }}\left(\mathrm{km}^{-1}\right) \&$ MERRA-2 relative humidity & -0.38 to -0.53 \\
\hline$B_{\text {ext }}\left(\mathrm{km}^{-1}\right) \&$ MERRA-2 temperature & 0.24 to 0.49 & $B_{\text {ext }}\left(\mathrm{km}^{-1}\right) \&$ MERRA-2 temperature & 0.33 to 0.49 \\
\hline $\begin{array}{l}B_{\text {ext }}\left(\mathrm{km}^{-1}\right) \& \text { MERRA-2 precipitation } \\
(* p \text { value }=0.0013)\end{array}$ & -0.09 to -0.37 & $B_{\text {ext }}\left(\mathrm{km}^{-1}\right) \&$ MERRA-2 precipitation & -0.16 to -0.35 \\
\hline $\begin{array}{l}B_{\text {ext }}\left(\mathrm{km}^{-1}\right) \& \text { GPCP precipitation } \\
(* p \text { value }=0.004)\end{array}$ & -0.07 to -0.35 & NA & NA \\
\hline $\begin{array}{l}B_{\text {ext }}\left(\mathrm{km}^{-1}\right) \& \text { TRMM precipitation } \\
(* p \text { value }=0.005)\end{array}$ & -0.07 to -0.35 & NA & NA \\
\hline $\begin{array}{l}B_{\text {ext }}\left(\mathrm{km}^{-1}\right) \& \text { CPC precipitation } \\
(* p \text { value }=0.007)\end{array}$ & -0.06 to -0.34 & $B_{\text {ext }}\left(\mathrm{km}^{-1}\right) \&$ CPC precipitation & -0.17 to -0.35 \\
\hline
\end{tabular}

NA - not available

monthly GFWED RH and DC variables (Table 1; Fig. 3c, e). However, statistical relationships among Bolivia monthly MODIS C6 fire data and mean monthly GFWED temperature and precipitation variables were still significant. Of all the GFWED variables, statistical relationships were strongest between mean monthly MODIS C6 fire data and DC (Table 1), showing clear seasonal covariation (Fig. 3e).

Inverse relationships between MODIS C6 and precipitation across MERRA-2, CPC, GPCP, and TRMM were all comparably low (Table 1). Of the precipitation sources analyzed, the strongest observed relationship was between Bolivia MODIS C6 and MERRA 2 precipitation data, with a $95 \%$ correlation confidence interval of -0.27 to -0.51 . A significant inverse relationship was observed between MODIS C6 active fire data and MERRA-2 RH, with a 95\% correlation confidence interval of -0.56 to -0.73 for lowland Bolivia. Next, a positive relationship can be seen between MODIS C6 active fire and MERRA-2 temperature data, with a $95 \%$ correlation confidence interval of 0.43 0.64 . Finally, stronger relationships were observed among MODIS C6 active fire data and TRMM DC, GPCP DC, and CPC DC, when compared to correlations between MODIS C6 active fire data and MERRA-2 DC. The strongest relationship for DC was between Bolivia MODIS C6 data and GPCP DC, with a $95 \%$ correlation confidence interval of $0.69-0.82$.

\subsection{Climate and fire relationships in NK}

For NK from 2001 to 2015, higher-than-normal (i.e.,

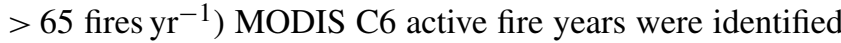
in 2003, 2004, 2005, 2007, 2010, and 2012 (Fig. 3f). Significant relationships were found among monthly NK MODIS C6 active fire data and mean monthly GFWED variables for NK (Table 1). Relationships among monthly NK MODIS C6 active fire data and mean monthly GFWED precipitation (Fig. 3g) and temperature (Fig. 3i) variables were weaker compared to relationships among monthly NK MODIS C6 active fire data and mean monthly GFWED RH and DC variables (Fig. 3h, j). The level of significance varied between monthly NK MODIS C6 active fire data and mean monthly GFWED precipitation correlations.

Precipitation and fire inverse relationships were even lower over NK than over Bolivia across all different precipitation estimates (Table 1). The strongest observed relationship for precipitation was between NK MODIS C6 and MERRA 2 precipitation, with a $95 \%$ correlation confidence interval of -0.07 to -0.35 . Next, a significant inverse relationship was observed between MODIS C6 active fire data and NK MERRA-2 RH, with a $95 \%$ correlation confidence interval of -0.21 to -0.47 . A positive relationship was seen between NK MODIS C6 active fire and MERRA-2 temperature data, with a $95 \%$ correlation confidence interval of 0.24 0.49 . Finally, significant relationships were found among NK MODIS C6 active fires and TRMM DC, GPCP DC, CPC DC, and MERRA 2 DC. Of the four DC values, the MERRA- 
Table 3. Mean fire season (i.e., August-October) Pearson's correlations (January 1982-December 2015) between $B_{\text {ext }}\left(\mathrm{km}^{-1}\right.$ ), and Global Fire WEather Database (GFWED) variables for lowland Bolivia. All correlation $p$ values were $<0.001$, unless otherwise noted.

\begin{tabular}{lr}
\hline Bolivia & $95 \%$ confidence interval \\
\hline$B_{\text {ext }}\left(\mathrm{km}^{-1}\right) \&$ CPC DC & 0.36 to 0.79 \\
$B_{\text {ext }}\left(\mathrm{km}^{-1}\right) \&$ MERRA-2 relative humidity & -0.25 to -0.74 \\
$B_{\text {ext }}\left(\mathrm{km}^{-1}\right) \&$ MERRA-2 DC $\left({ }^{*} p\right.$ value $\left.=0.007\right)$ & 0.13 to 0.68 \\
$B_{\text {ext }}\left(\mathrm{km}^{-1}\right) \&$ MERRA-2 precipitation $\left({ }^{*} p\right.$ value $\left.=0.014\right)$ & -0.10 to -0.66 \\
$B_{\text {ext }}\left(\mathrm{km}^{-1}\right) \&$ CPC precipitation $\left({ }^{*} p\right.$ value $\left.=0.046\right)$ & -0.008 to -0.61 \\
$B_{\text {ext }}\left(\mathrm{km}^{-1}\right) \&$ MERRA-2 temperature $\left({ }^{*} p\right.$ value $\left.=0.13\right)$ & -0.08 to 0.55 \\
\hline
\end{tabular}

2 DC had the weakest relationship to NK MODIS C6 active fires. The strongest relationship for DC was between MODIS C6 active fire data and TRMM DC, with a $95 \%$ correlation confidence interval of $0.39-0.61$.

\subsection{Spatial distribution of fire and DC}

During 2010, fire was widespread (Fig. 4a) and September GPCP DC values were higher and spatially coherent in northeastern Bolivia (Fig. 4b). During 2014, fire was less active in lowland Bolivia (Fig. 4c) and GPCP DC during September was lower than in 2010 (Fig. 4d). Outside of NK, fire occurred in the Cerrado, SDTF, METF, and seasonally inundated wetland biomes (Fig. 4a, c). Within NK, 223 MODIS C6 active fires were observed in 2010 (Fig. 4a), and 17 MODIS C6 active fires were observed in 2014 (Fig. 4c). During both years, fires in NK occurred primarily in the Cerrado biome on the Huanchaca plateau.

\subsection{Fire and forest loss}

Forest loss from 2000 to 2012 largely corresponded to areas where MODIS C6 fires occurred from 2001 to 2015 (Fig. 5). Within NK, the majority of forest loss can be found on the Huanchaca plateau where the Cerrado biome is found, along the Cerrado-METF boundary, and in seasonally inundated wetlands. Overall, forest loss is minimal within NK compared to the unprotected areas adjacent to NK (Fig. 5). For unprotected areas outside of NK, forest loss occurred in the Cerrado, SDTF, METF, and seasonally inundated wetland biomes, and in urban and agriculture land use zones (Fig. 5). Forest loss outside of NK largely corresponded to areas where fire also occurred (Fig. 5).

\subsection{Seasonal and interannual relationships between $B_{\text {ext }}$ and GFWED data in lowland Bolivia}

Overall, mean monthly correlations among monthly MODIS C6 fire and mean monthly GFWED variables (Table 1) were stronger than mean monthly correlations among $B_{\text {ext }}$ and GFWED variables from 2001 to 2015 (Table 2). In particular, correlations among $B_{\text {ext }}$ and GFWED precipitation and temperature variables were slightly weaker when compared to the same correlations using MODIS C6 fire data. Nevertheless, significant mean monthly correlations were observed among $B_{\text {ext }}$ and GFWED DC and RH from January 2001 to December 2015 (Table 2), suggesting seasonal covariation between $B_{\text {ext }}$ and DC.

Over the longer record from 1982 to 2015, significant correlations were observed between mean fire season $B_{\text {ext }}$ and GFWED data (Table 3; Fig. 6). The strongest relationships were observed among mean fire season $B_{\text {ext }}$ and GFWED DC and RH variables (Fig. 6b, d), with a tendency towards interannual covariation between $B_{\text {ext }}$ and DC. Relationships between mean fire season $B_{\text {ext }}$ and precipitation were significant (Fig. 6a), but overall weak. While interannual covariation is seen between $B_{\text {ext }}$ and temperature from 1982 to 1993 (Fig. 6c), the relationship between mean fire season $B_{\text {ext }}$ and temperature was not significant from 1982 to 2015 (Table 3).

\section{Discussion}

\subsection{Drivers of fire in lowland Bolivia and NK}

From 2001 to 2015, our analyses reveal strong fire seasonality in lowland Bolivia (Fig. 2a) and NK (Fig. 2b). Within NK, drought conditions were the main driver of fire (e.g., Table 1; Fig. 3j), while fires in unprotected areas of lowland Bolivia were controlled by a combination of drought (e.g., Figs. 3e, 4b, 6d), biome type (e.g., Fig. 5), and forest loss likely influenced by human activities (Fig. 5). Driving drought conditions in lowland Bolivia are oceanic oscillations including El Niño-Southern Oscillation (Aragão et al., 2007; Bush et al., 2008; Asner and Alencar, 2010; Marengo et al., 2011), the Madden-Julian Oscillation (Marengo et al., 2011), and Atlantic sea-surface temperature (SST) variability (Vera et al., 2006; Aragão et al., 2007; Yoon and Zeng, 2010). Oceanic oscillations alter atmospheric circulation associated with the South American monsoon (Vera et al., 2006; Aragão et al., 2007; Yoon and Zeng, 2010; Marengo et al., 2011), causing precipitation deficits and region-wide drought in the southwestern Amazon during the wet season (October-November to April-May) (Aragão et al., 2007; Yoon and Zeng, 2010).

High-fire years in 2005, 2007, and 2010 (Fig. 3a, f) correspond to years of drought (Lewis et al., 2011; Chen et al., 


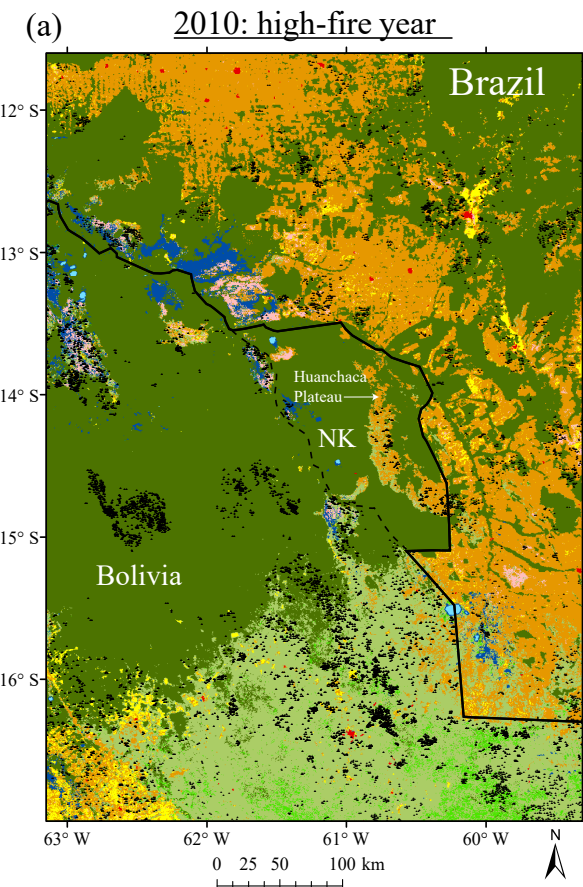

(b)

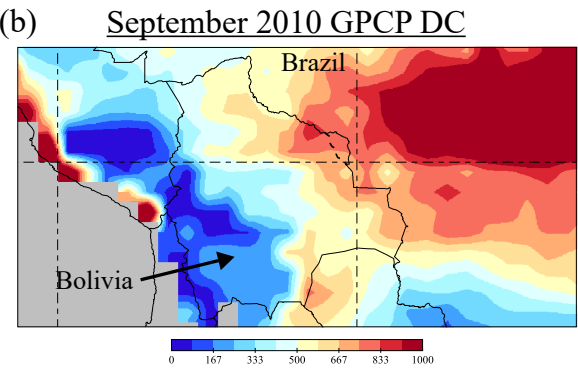

2014: low-fire year

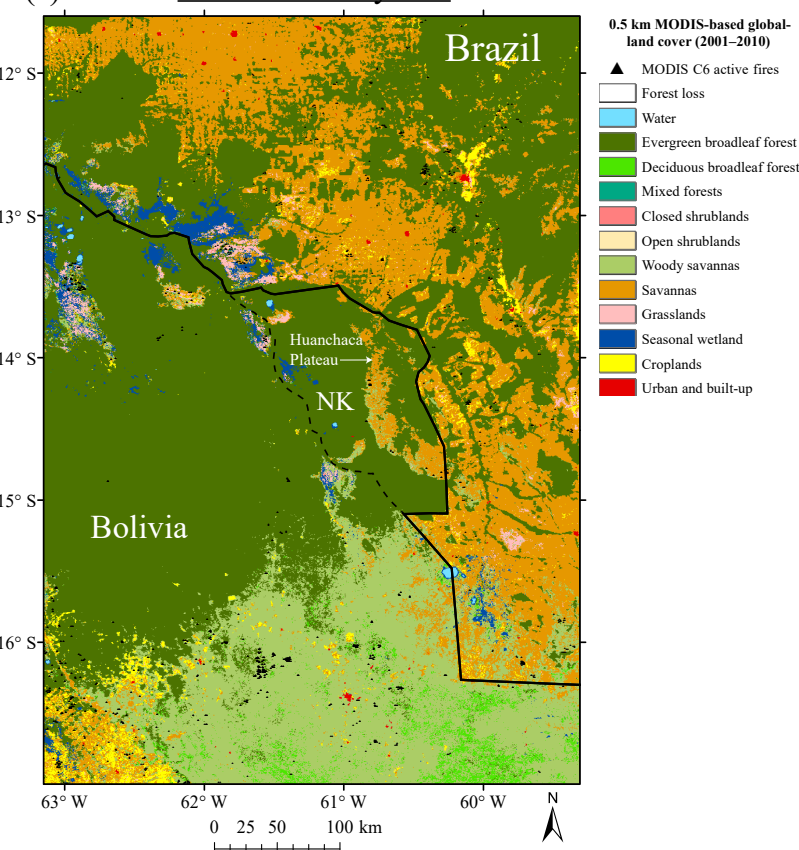

(d) September 2014 GPCP DC

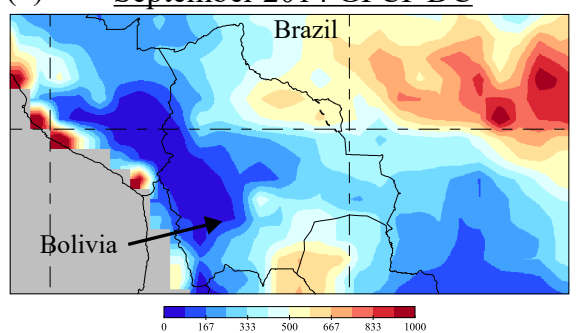

Figure 4. Moderate Resolution Imaging Spectroradiometer C6 (MODIS C6) active fires with $\geq 90 \%$ confidence during 2010, a high-fire year (a), and during 2014, a low-fire year (c). September GPCP Drought Code (DC) during 2010 (b) and 2014 (d). MODIS-based Collection 5.1 MCD12Q global land cover data (Broxton et al., 2014) are included. Noel Kempff Mercado National Park (NK) is the area that falls within the dotted black polyline and the Bolivia-Brazil border.

2013b) and high-fire years in the southern Amazon identified by others (Chen et al., 2013b; van Marle et al., 2017). Prolonged drought conditions in the southern Amazon are caused by reduced rainfall, higher-than-normal temperatures, and reduced atmospheric moisture during the wet and dry seasons (Marengo et al., 2008). Our results suggest the CPC DC (Fig. 3e) and regional $B_{\text {ext }}$ (Table 2; Fig. 3a) captured interannual drought variability that impacted the southern Amazon during the early 2000s. In addition to high DC values regionally, low RH (Fig. 3c) and high temperature (Fig. 3d) were linked to increased fire activity in lowland Bolivia and NK (Table 1). Further demonstrating the connection between drought and fire in NK and lowland Bolivia were drought years and non-drought years, when fire was either significantly enhanced (Fig. 4a) or reduced (Fig. 4c). In particular, GPCP DC values were higher in lowland Bolivia during 2010, a high-fire year (Fig. 4a, c), and GPCP DC values were lower during 2014, a low-fire and low-DC year (Fig. 4b, d). Our results are consistent with others who found synchronous changes in fire activity between tropical forest and Cerrado biomes in the Amazon (Chen et al., 2013b). During 2014, fire in NK and the surrounding unprotected areas was significantly reduced across all biomes (Fig. 4b). The opposite occurred in 2010, when drought conditions and increased fire activity were observed across all biomes during the fire season (Fig. 4a, c).

While our results and paleosedimentary records (Burbridge et al., 2004; Maezumi et al., 2015) show fires are frequent on the Cerrado landscape in NK (Killeen et al., 2002), determining if drought, human activities, or a combination of both were the dominant drivers of recent fire activity in the SDTF and METF biomes in lowland Bolivia is less understood. Considering unfragmented tropical Amazon forests are more resilient to fire and drought conditions 


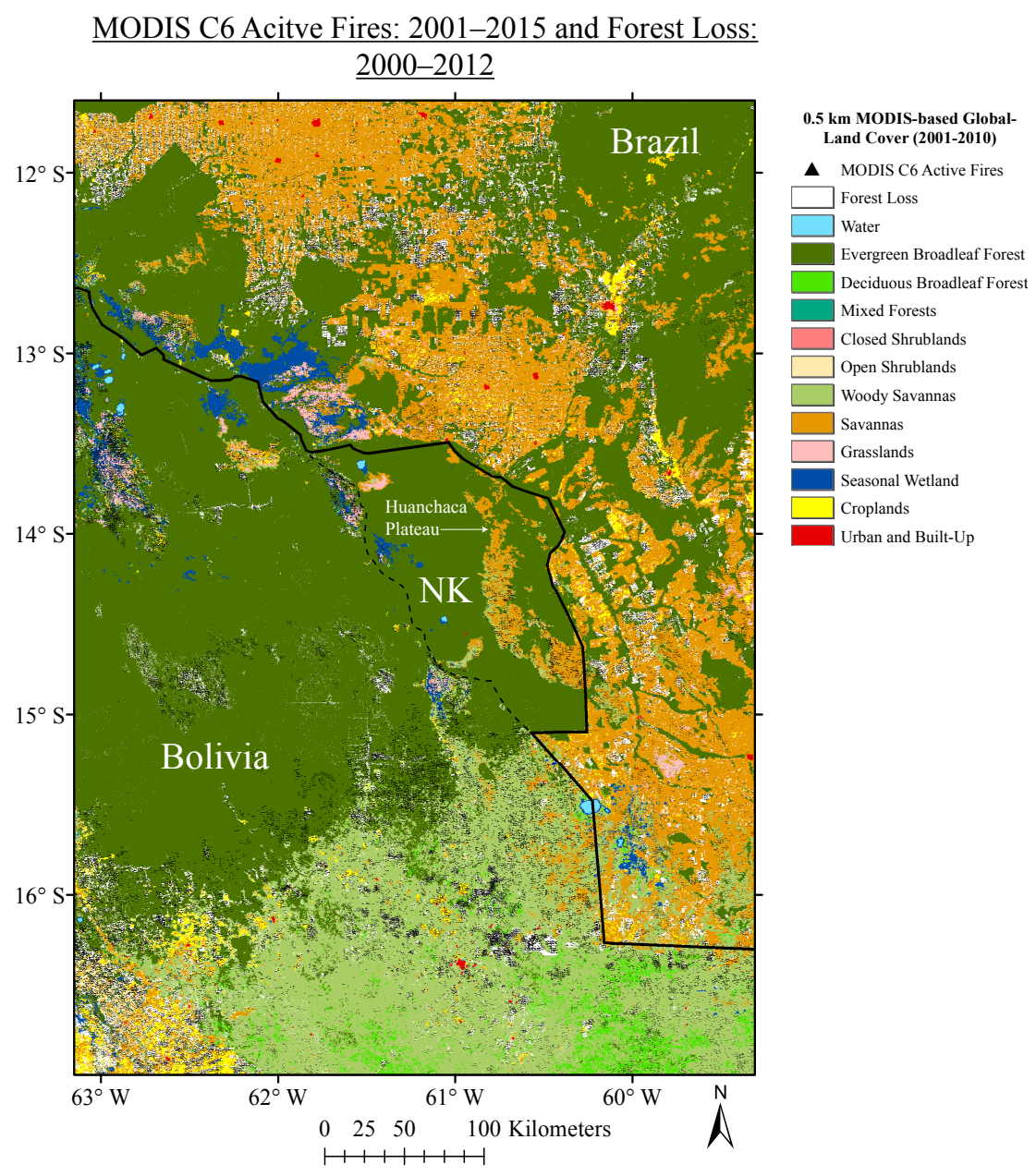

Figure 5. Forest loss from 2000 to 2012 (Hansen et al., 2013) displayed in white (a), and Moderate Resolution Imaging Spectroradiometer C6 (MODIS C6) active fires with $\geq 90 \%$ confidence from 2001-2015 (b). MODIS-based Collection 5.1 MCD12Q global land cover data (Broxton et al., 2014) are included. NK is the area that falls within the dotted black polyline and the Bolivia-Brazil border.

(Cochrane, 2003; Davidson et al., 2012) than fragmented tropical Amazon forests (Nepstad et al., 1999; Laurance and Williamson, 2001; Fearnside, 2005; Chen et al., 2013b), we suggest the spatial correspondence of forest loss and fire in METF biomes outside of NK (Fig. 5) was associated with forest clearing activities for economic practices common in the area (e.g., Killeen et al., 2008; Fearnside, 2017).

Seen as forest loss (Fig. 5), the logging of Amazon forests has increased dry surface fuels, suppressed soil moisture, and created an environment susceptible to fire during drought (Nepstad et al., 1999; Fearnside, 2005; Chen et al., 2013a, b). Large geometric rectangular areas of forest loss observed in METF biomes and other biomes surrounding NK indicate forest loss from fire was not from lighting ignitions alone. While we did not directly monitor human activities, our results suggest human activities further amplified forest loss and fire during high-DC years. Spatial coherency between fire and forest loss seen in our results, and the results of oth- ers, suggests fire in the SDTF and METF biomes is a function of human and lighting ignitions amplified by drought during the historical record (Killeen et al., 2002; Brown et al., 2006) and the paleorecord (Bush et al., 2008). However, an area of fire and forest loss seen in the METF west of NK appears spatially random, and not necessarily because of human activities alone (Fig. 4a).

Spatial correspondence among fire, high DC, and forest loss in the METF biome west of NK is observed in 2010 (Fig. 4a, c), indicating high DC (i.e., drought) was the dominant control on fire and forest loss. Drought was not limited to lowland Bolivia in 2010. Rather, severe drought was observed across much of the Amazon basin (Lewis et al., 2011). The drought in 2010 was linked to high Atlantic SSTs and intensified El Niño conditions (Lewis et al., 2011). While our research focuses on small-spatial-scale interactions between fire and local to regional climate variability, oceanic oscillations impact drought in the Amazon (e.g., Aragão 
(a)

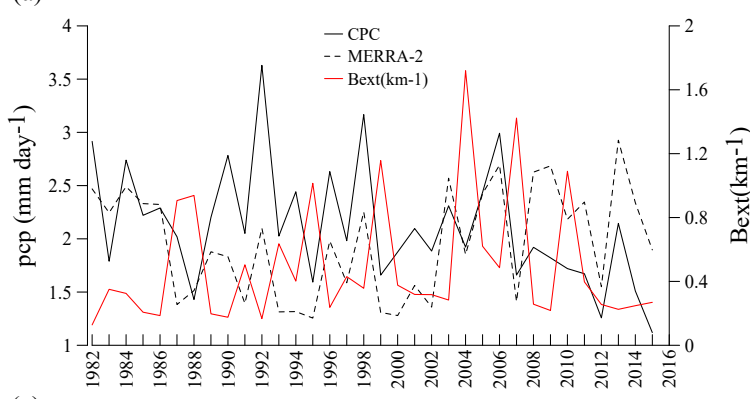

(c)

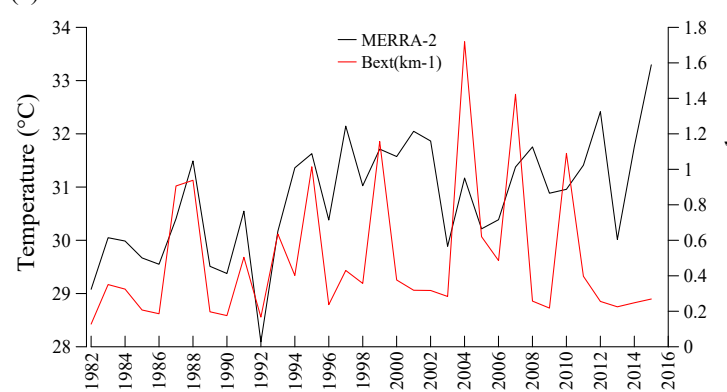

(b)

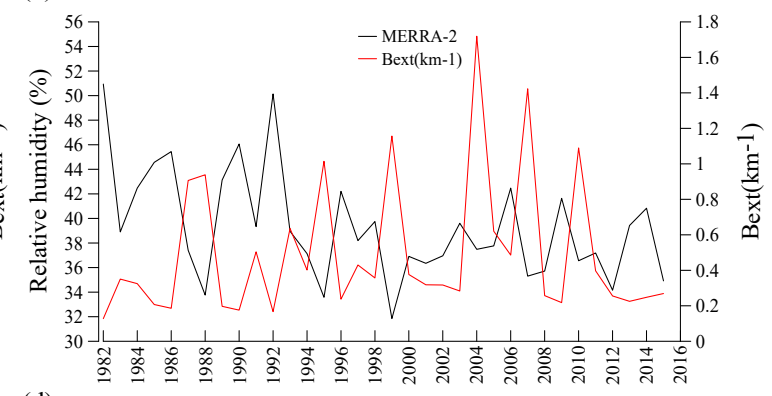

(d)

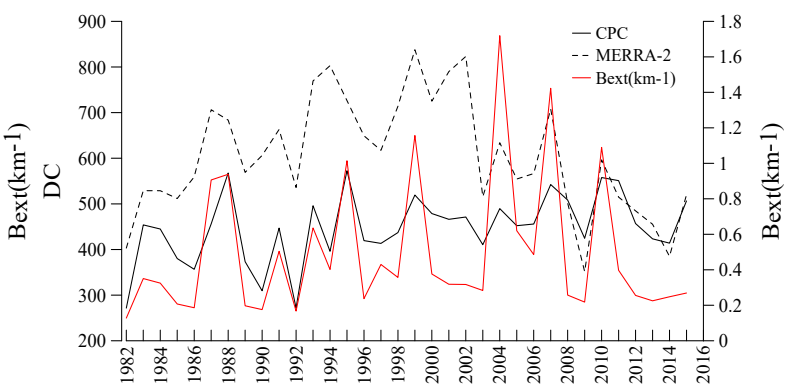

Figure 6. Mean fire season (August-October) time series (1982-2015) of daily Global Fire WEather Database (GFWED) variables for Bolivia including MERRA-2 precipitation (a), MERRA-2 relative humidity (b), MERRA-2 temperature (c), and CPC and MERRA-2 DC (d). $B_{\text {ext }}\left(\mathrm{km}^{-1}\right)$ are included in each plot (i.e., red line).

et al., 2007), and likely influenced high-fire years in lowland Bolivia during 2004, 2005, 2007, 2008, 2010, and 2011 (Fig. 3a).

\subsection{Fire relationship to different biomes}

Fire within NK is a function of biome type (Figs. 1b, 4, 5). In NK, fires ignited by lighting are frequent in the Cerrado biome from August to October (Killeen et al., 2002). Consistent with Cochrane (2003), a lack of fire activity was observed in the METF biome in NK from 2001 to 2015. Fire during the MODIS C6 record in lowland Bolivia and in NK was largely restricted to the Cerrado and seasonally inundated wetland biomes.

Biome boundary dynamics among the Cerrado and other biomes influence fire in the southern Amazon (Power et al., 2016). Extreme seasonal droughts can amplify the role of fire on biome boundaries among the Cerrado, SDTF, and METF. The drying out of plant biomass and soil moisture increases the potential for Cerrado grassland fire propagation into neighboring biomes (Power et al., 2016). Amazon forest boundaries are vulnerable to positive feedbacks linked to forest loss and climate-induced drought that increase forest fragmentation and fire propagation (Laurance and Williamson, 2001). Unprotected areas outside of NK show evidence of biome boundary dynamics related to fire and forest loss (Fig. 5). The majority of fires in the METF are observed at biome boundary interfaces. Both biome boundary dynamics and human-caused forest loss seem to have affected fire in the SDTF and METF biomes during our study.

\subsection{Using visibility data as a proxy of interannual fire emissions in lowland Bolivia}

We suggest $B_{\text {ext }}$ visibility data were a proxy of regional interannual fire emissions from 1982 to 2015 . High mean fire season $B_{\text {ext }}$ in 1987, 1988, 1995, and 1999 could have been related to increased fire activity (Fig. 6). The five lowest visibility (i.e., high $B_{\text {ext }}$ ) years from 1982 to 2015 were observed towards the end of the visibility record in 1995, 1999, 2004, 2007, and 2010, corresponding to high MODIS C6 fire years in 2004, 2007, and 2010 (Fig. 3a). Our results are consistent with van Marle et al. (2017), who identified higherthan-normal particulate matter emitted into the atmosphere over the southwestern Amazon in 1988, 1995, 1999, 2004, 2007, and 2010. Consistency between our results and those of van Marle et al. (2017) suggests $B_{\text {ext }}$ visibility, with limitations in mind (van Marle et al., 2017), can be used as a proxy of regional fire emissions for the southwestern Amazon and lowland Bolivia. Further supporting our findings are results showing fires in the Amazon cause the entrainment of smoke into the upper atmosphere, which enhances convective storms and lightning (Andreae et al., 2004). Correspondence between low-visibility and high-fire years in low- 
land Bolivia (Fig. 3a) suggests smoke emitted during highfire years could have enhanced convective storms and further amplified natural ignitions and fire.

Statistical relationships further suggest $B_{\text {ext }}$ can be used as a proxy of interannual fire emission variability in lowland Bolivia. Significant statistical relationships were found between mean monthly $B_{\text {ext }}$ and monthly MODIS C6 fire data from 2001 to 2015 (Fig. 2), between mean monthly $B_{\text {ext }}$ and mean monthly GFWED variables from 2001 to 2015 (Table 2), and between mean fire season $B_{\text {ext }}$ and mean fire season GFWED variables from 1982 to 2015 (Table 3). Of the GFWED variables, seasonal covariation was strongest between $B_{\text {ext }}$ and DC from 2001 to 2015 (Fig. 3a, e). Interannual covariation was strongest between $B_{\text {ext }}$ and DC from 1982 to 2015 (Fig. 6d). Both seasonal and interannual covariation between $B_{\text {ext }}$ and DC suggest visibility related to smoke emissions in lowland Bolivia was influenced by seasonal to interannual DC variability impact on fire activity. From 1982 to 2015 , the strongest correlations (Table 3) were between mean fire season CPC DC (i.e., August-October) and mean fire season $B_{\text {ext }}$ (i.e., August-October). The next strongest correlation was between mean fire season MERRA-2 RH and mean fire season $B_{\text {ext }}$. Our results suggest from 2001 to 2015 , and from 1982 to 2015, regional fire activity in Bolivia was affected by interannual DC and RH variability.

\subsection{Considerations and implications of GFWED and WMO visibility data}

We speculate antecedent dry conditions linked to precipitation and temperature anomalies prior to the fire season impacted high DC values and fire in Bolivia and NK. When southern Amazon wet season drought is severe, terrestrial water storage deficits can amplify drought and fire severity during the subsequent dry season (Chen et al., 2013a). Wet season drought leading to drought and fire seems plausible considering the DC is used here as an indicator of heavy surface fuel drying over several months and deep organic soil moisture content (Field et al., 2015). Further, this would explain weaker linear correlations observed among fire, $B_{\text {ext }}$, precipitation, and temperature. We recommend future studies investigating climate and fire relationships in tropical and subtropical ecosystems use the DC as an indicator of antecedent dry conditions.

Knowing the importance of DC as an indicator of antecedent dry conditions that influence fire and visibility (e.g., $B_{\text {ext }}$ ), future studies using DC should consider various precipitation sources when calculating the parameter. DC values were less biased when using TRMM and GPCP precipitation, and demonstrated a strong correlation with MODIS C6 fire data for lowland Bolivia and NK (Table 1). MERRA-2 DC and CPC DC values were consistently higher than TRMM DC and GPCP DC values for both lowland Bolivia and NK from 2001 to 2015. MERRA-2 DC values exceeded 800 for lowland Bolivia and 1000 for NK, much higher than TRMM and GPCP values.

In addition to the GFWED data used in our study, errors associated with the WMO visibility data are important to consider. Visibility data are vulnerable to errors related to human-observed measurements and are derived from spatially inconsistent weather stations distributed in the Amazon region (van Marle et al., 2017). Because of the role variable smoke transport has in relationships between fire activity and visibility, we have limited our visibility to only the broadest relationships across the large lowland area of Bolivia. We note, however, that the regional visibility signal was relatively insensitive to whether it was calculated from 4, 6, 8, or 11 stations (Fig. S1 in the Supplement).

Given these limitations, our results demonstrate (i.e., 2001-2015) connections among fire in lowland Bolivia, $B_{\text {ext }}$ variability (Fig. 2), interannual climate variability (Figs. 3, 4, 6), biome type (e.g., Fig. 4), forest loss (Fig. 5), and biome boundary dynamics (e.g., Fig. 5). Future climate changes could impact drought severity and fire activity in lowland Bolivia. From 1979 to 1996, fire season length decreased, or did not change in lowland Bolivia (Jolly et al., 2015). However, from 1996 to 2013, fire season length increased in the Brazilian Amazon north and east of lowland Bolivia (Jolly et al., 2015), corresponding to a period of increased emissions in the southern Amazon (van Marle et al., 2017) and lowland Bolivia (Fig. 6). In the Amazon basin, a projected increase in FWI is expected for the period 2026-2045 (Bedia et al., 2015), and fire season severity is expected to increase during the 21 st century (Flannigan et al., 2013). Projections of fire season length increasing, FWI increasing, and fire severity increasing (Flannigan et al., 2013) are of concern for lowland Bolivia when considering our results, and the impacts drought conditions have on increased fire activity in lowland Bolivia are also of concern. A drier climate and associated fire in the Amazon could promote a transition from seasonally inundated wetlands to savannah vegetation, which could allow savanna forest expansion into the tropical Amazon and create an environment more susceptible to fire (Flores et al., 2017). Our results (Fig. 4) and the results of others (e.g., Flores et al., 2017) indicate seasonally inundated wetlands and Cerrado forests are vulnerable to fire associated with drought, suggesting these biomes need to be carefully considered if drought in the Amazon occurs more frequently in the future. We provide further understanding of how different biomes have recently responded to drought and fire in lowland Bolivia, which is important when considering uncertainties regarding the fate of the Amazon (Zhang et al., 2015).

While increased FWI and fire severity are a concern for lowland Bolivia and for carbon emissions and global climate, fire leading to forest loss in the METF biome within NK was not observed from 2001 to 2015 (Figs. 2b, 4, 5). Our results suggest if human activities that amplify fire in the southern Amazon were restricted, recent fire activity could 
have been reduced in the METF biome. Considering the spatial distribution of fires in NK, and the spatial coherence of forest loss and fire in the unprotected METF biome outside of NK (Fig. 5), a major limitation of our study is that we did not quantify the amount of forest loss in lowland Bolivia from human activities. As mentioned by others (e.g., Bedia et al., 2015), to better understand potential impacts of fire on southern Amazon tropical forests, human activities causing forest loss and fire need to be considered. To minimize deforestation and fire in the southern Amazon, our results (e.g., Fig. 5) and those of others (Flannigan et al., 2013) suggest human ignitions need to be reduced. Considering deforestation in the Brazilian Amazon has increased since 2012 (Fearnside, 2017), and in the southern Amazon Cerrado biome since 2010 (Soares-Filho et al., 2014), land use incentives and agricultural policies implemented to reduce deforestation in parts of the Brazilian Amazon (Nepstad et al., 2014) need to be enforced throughout the Amazon. In lowland Bolivia, if land use incentives and agricultural policies to reduce deforestation are not implemented and enforced, and the demand for Amazon resources continues to increase (Fearnside, 2017), future anthropogenic deforestation and fire could worsen, particularly when drought occurs (e.g., Fig. 4a, c).

\section{Conclusions}

We have demonstrated how multiple data can be used to explore seasonal and interannual relationships among climate, fire, land use, forest loss, and smoke emissions. A key finding, high DC and low humidity were dominant causes of recent fire activity in unprotected and protected areas of lowland Bolivia. In addition, fire was likely enhanced by fragmented biomes because of human activities, seen as forest loss in our results. Of interest to biogeographers, fires in NK from 2001 to 2015 occurred primarily in the Cerrado biome and in seasonally inundated wetlands, and were absent from the NK METF biome with the exception of Cerrado-METF biome interfaces. Considering fire was minimal in the NK METF biome from 2001 to 2015, we recommend tropical forests in the southern Amazon and lowland Bolivia need further protection from human ignitions and deforestation. Further, considering Cerrado and seasonally inundated wetland susceptibility to fire when drought occurs, attention should be given to Cerrado expansion into seasonally inundated wetlands and METF biomes.

In addition to exploring climate, fire, land use, and biome relationships, our results demonstrate how differences among precipitation estimates used to calculate DC can bias DC values (e.g., MERRA-2, CPC, GPCP, and TRMM). Differing DC values because of precipitation estimate uncertainties demonstrate the importance of using multiple data sources when considering relationships among climate, fire, land use, forest loss, and smoke emissions. By using multiple data sources, we were able to extend the historical fire record for lowland Bolivia using $B_{\text {ext }}$ visibility data. Our results and the results of others suggest visibility data can be used as a proxy of regional fire emissions in the southwestern Amazon and lowland Bolivia. Based on our results and the results of others, we recommend future studies interested in extending regional fire records should consider using multiple data sources including MODIS active fire, GFWED, and WMO visibility data.

Data availability. MODIS C6 data can be obtained at https://earthdata.nasa.gov/earth-observation-data/near-real-time/ firms/active-fire-data (last access: Feburary 2017). GFWED data are available at https://data.giss.nasa.gov/impacts/gfwed/ (last access: Feburary 2017). Data used to calculate horizontal visibility can be obtained from https://catalog.data.gov/ dataset/integrated-surface-global-hourly-data (last access: Feburary 2017). MODIS-based Global Land Cover Climatology data are available at https://landcover.usgs.gov/global_climatology.php (last access: Feburary 2017). Global Forest Change Landsat data can be found at https://earthenginepartners.appspot.com/ science-2013-global-forest/download_v1.2.html (last access: Feburary 2017).

\section{The Supplement related to this article is available online at https://doi.org/10.5194/bg-15-4317-2018-supplement.}

Author contributions. All authors contributed to writing and revising the manuscript. JPH was responsible for collecting MODIS C6 and Landsat data, performing statistical analyses, and analyzing all data used. MJP provided expertise on fire and climate data. RDF collected and provided expertise on GFWED and horizontal visibility data. MJEvM collected and provided expertise on horizontal visibility data.

Competing interests. The authors declare that they have no conflict of interest.

Acknowledgements. This material is based upon work supported by the National Science Foundation Graduate Research Fellowship under grant 1256065. Any opinion, findings, and conclusions or recommendations expressed in this material are those of the authors(s) and do not necessarily reflect the views of the National Science Foundation. Robert D. Field was supported by the NASA Precipitation Measurement Missions Science Team and the NASA Modeling, Analysis and Prediction Program.

Edited by: Jochen Schöngart

Reviewed by: three anonymous referees 


\section{References}

Andreae, M. O., Rosenfeld, D., Artaxo, P., Costa, A. A., Frank, G. P., Longo, K. M., and Silva-Dias, M. A. F.: Smoking rain clouds over the Amazon, Science, 303, 1337-1342, 2004.

Aragão, L. E., Malhi, Y., Roman-Cuesta, R. M., Saatchi, S., Anderson, L. O., and Shimabukuro, Y. E.: Spatial patterns and fire response of recent Amazonian droughts, Geophys. Res. Lett., 34, L07701, https://doi.org/10.1029/2006GL028946, 2007.

Aragão, L. E., Poulter, B., Barlow, J. B., Anderson, L. O., Malhi, Y., Saatchi, S., Phillips, O. L., and Gloor, E.: Environmental change and the carbon balance of Amazonian forests, Biol. Rev., 89, 913-931, 2014.

Asner, G. P. and Alencar, A.: Drought impacts on the Amazon forest: the remote sensing perspective, New Phytol., 187, 569-578, 2010.

Bedia, J., Herrera, S., Gutiérrez, J. M., Benali, A., Brands, S., Mota, B., and Moreno, J. M.: Global patterns in the sensitivity of burned area to fire-weather: Implications for climate change, Agr. Forest Meteorol., 214, 369-379, 2015.

Brown, I. F., Schroeder, W., Setzer, A., De Los Rios Maldonado, M., Pantoja, N., Duarte, A., and Marengo, J.: Monitoring Fires in Southwestern Amazonia Rain Forests, EOS T. Am. Geophys. Un., 87, 253-264, 2006.

Broxton, P. D., Zeng, X., Sulla-Menashe, D., and Troch, P. A.: A Global Land Cover Climatology Using MODIS Data, J. Appl. Meteorol. Clim., 53, 1593-1605, https://doi.org/10.1175/JAMCD-13-0270.1, 2014.

Burbridge, R, E., Mayle, F. E., and Killeen, T. J.: Fifty-thousandyear vegetation and climate history of Noel Kempff Mercado National Park, Bolivian Amazon, Quaternary Res., 61, 215-230, 2004.

Bush, M. B., Silman, M. R., McMichael, C., and Saatchi, S.: Fire, climate change and biodiversity in Amazonia: a Late-Holocene perspective, Philos. T. Roy. Soc. B, 363, 1795-1802, 2008.

Chen, M., Shi, W., Xie, P. P., Silva, V. B. S., Kousky, V. E., Higgins, R. W., and Janowiak, J. E.: Assessing objective techniques for gauge-based analyses of global daily precipitation, J. Geophys. Res., 113, D04110, https://doi.org/10.1029/2007JD009132, 2008.

Chen, Y., Velicogna, I., Famiglietti, J. S., and Randerson, J. T.: Satellite observations of terrestrial water storage provide early warning information about drought and fire season severity in the Amazon, J. Geophys. Res.-Biogeo., 118, 495-504, 2013a.

Chen, Y., Morton, D. C., Jin, Y., Collatz, G. J., Kasibhatla, P. S., van der Werf, G. R., DeFries, R. S., and Randerson, J. T.: Long-term trends and interannual variability of forest, savanna and agricultural fires in South America, Carbon Manage., 4, 617-638, https://doi.org/10.4155/cmt.13.61, 2013b.

Cochrane, M. A.: Fire science for rainforests, Nature, 421, 913-919, https://doi.org/10.1038/nature01437, 2003.

Cochrane, M. A. and Barber, C. P.: Climate change, human land use and future fires in the Amazon, Glob. Change Biol., 15, 601-612, 2009.

Davidson E. A., de Araújo, A. C., Artaxo, P., Balch, J. K., Brown, I. F., Bustamante, M. M., Coe, M. T., DeFries, R. S., Keller, M., Longo, M., and Munger, J. W.: The Amazon basin in transition, Nature, 481, 321-328, https://doi.org/10.1038/nature10717, 2012. de Groot, W. J. and Flannigan, M. D.: Climate change and early warning systems for wildland fire, in: Reducing Disaster: Early Warning Systems For Climate Change, 127-151, Springer, Dordrecht, 2014.

Fearnside, P.: Business as usual: a resurgence of deforestation in the Brazilian Amazon, Yale Environ., 360, 1-6, 2017.

Fearnside, P. M.: Deforestation in Brazilian Amazonia: history, rates, and consequences, Conserv. Biol., 19, 680-688, 2005.

Field, R. D., van der Werf, G. R., and Shen, S. S.: Human amplification of drought-induced biomass burning in Indonesia since 1960, Nat. Geosci., 2, 185-188, 2009.

Field, R. D., Spessa, A. C., Aziz, N. A., Camia, A., Cantin, A., Carr, R., de Groot, W. J., Dowdy, A. J., Flannigan, M. D., Manomaiphiboon, K., Pappenberger, F., Tanpipat, V., and Wang, X.: Development of a Global Fire Weather Database, Nat. Hazards Earth Syst. Sci., 15, 1407-1423, https://doi.org/10.5194/nhess-15-1407-2015, 2015.

Field, R. D., van der Werf, G. R., Fanin, T., Fetzer, E. J., Fuller, R., Jethva, H., Levy, R., Livesey, N., Luo, M., Torres, O., and Worden, H. M.: Indonesian fire activity and smoke pollution in 2015 show persistent nonlinear sensitivity to El Niño-induced drought, P. Natl. Acad. Sci. USA, 113, 9204-9209, 2016.

Flannigan, M., Cantin, A. S., De Groot, W. J., Wotton, M., Newbery, A., and Gowman, L. M.: Global wildland fire season severity in the 21st century, Forest Ecol. Manage., 294, 54-61, 2013.

Flores, B. M., Holmgren, M., Xu, C., van Nes, E. H., Jakovac, C. C., Mesquita, R. C., and Scheffer, M.: Floodplains as an Achilles' heel of Amazonian forest resilience, P. Natl. Acad Sci. USA, 4442-4446, 2017.

Gelaro, R., McCarty, W., Suárez, M. J., Todling, R., Molod, A., Takacs, L., Randles, C. A., Darmenov, A., Bosilovich, M. G., Reichle, R., and Wargan, K.: The Modern-Era Retrospective Analysis for Research and Applications, Version 2 (MERRA2), J. Climate, 30, 5419-5454, 2017.

Giglio, L., Shroeder, W., and Justice, C. O.: The collection 6 MODIS active fire detection algorithm and fire products, Remote Sens. Environ., 178, 31-41, 2016.

Hansen, M. C., Potapov, P. V., Moore, R., Hancher, M., Turubanova, S., Tyukavina, A., Thau, D., Stehman, S. V., Goetz, S. J., Loveland, T. R., and Kommareddy, A.: "High-Resolution Global Maps of 21st-Century Forest Cover Change", Science, 342, 85053, 2013.

Huffman, G. J., Adler, R. F., Bolvin, D. T., and Gu, G.: Improving the global precipitation record: GPCP Version 2.1, Geophys. Res. Lett., 36, L17808, https://doi.org/10.1029/2009g1040000, 2009.

Huffman, G. J., Adler, R. F., Bolvin, D. T., Gu, G., Nelkin, E. J., Bowman, K. P., Hong, Y., Stocker, E. F., and Wolff, D. B.: The TRMM multisatellite precipitation analysis (TMPA): Quasiglobal, multiyear, combined-sensor precipitation estimates at fine scales, J. Hydrometeorol., 8, 38-55, https://doi.org/10.1175/jhm560.1, 2007.

Husar, R. B., Husar, J. D., and Martin, L.: Distribution of continental surface aerosol extinction based on visual range data, Atmos. Environ., 34, 5067-5078, 2000.

Jolly, W. M., Cochrane, M. A., Freeborn, P. H., Holden, Z. A., Brown, T. J., Williamson, G. J., and Bowman, D. M.: Climateinduced variations in global wildfire danger from 1979 to 2013 , Nat. Commun., 6, 7537, https://doi.org/10.1038/ncomms8537, 2015. 
Junk, W. J., Piedade, M. T. F., Schöngart, J., Cohn-Haft, M., Adeney, J. M., and Wittmann, F.: A classification of major naturally-occurring Amazonian lowland wetlands, Wetlands, 31, 623-640, 2011.

Killeen, T. J., Siles, T. M., Grimwood, T., Tieszen, L. L., Steininger, M. K., Tucker, C. J., and Panfil, S.: Habitat heterogeneity on a forest-savannah ecotone in Noel Kempff Mercado National Park (Santa Cruz, Bolivia): implications for the long-term conservation of biodiversity in a changing climate, in: How landscapes change: human disturbance and ecosystem fragmentation in the Americas, Vol. 162, edited by: Bradshaw, G. A. and Marquet, P. A., 285-312, Springer, Berlin, Heidelberg, 2002.

Killeen, T. J., Guerra, A., Calzada, M., Correa, L., Calderon, V., Soria, L., Quezada, B., and Steininger, M. K.: Total historical land-use change in eastern Bolivia: Who, where, when, and how much?, Ecol. Soc., 13, 36, https://www.ecologyandsociety.org/ vol13/iss1/art36/ (last access: 12 July 2018), 2008.

Laurance, W. F. and Williamson, G. B.: Positive feedbacks among forest fragmentation, drought, and climate change in the Amazon, Conserv. Biol., 15, 1529-1535, 2001.

Lewis, S. L., Brando, P. M., Phillips, O. L., van der Heijden, G. M., and Nepstad, D.: The 2010 amazon drought, Science, 331, 554-554, 2011.

Maezumi, S. Y., Power, M. J., Mayle, F. E., McLauchlan, K. K., and Iriarte, J.: Effects of past climate variability on fire and vegetation in the cerrãdo savanna of the Huanchaca Mesetta, NE Bolivia, Clim. Past, 11, 835-853, https://doi.org/10.5194/cp-11835-2015, 2015.

Marengo, J. A., Nobre, C. A., Tomasella, J., Cardoso, M. F., and Oyama, M. D.: Hydro-climatic and ecological behaviour of the drought of Amazonia in 2005, Philos. T. Roy. Soc. B, 363, $1773-$ 1778, 2008.

Marengo, J. A., Tomasella, J., Alves, L. M., Soares, W. R., and Rodriguez, D. A.: The drought of 2010 in the context of historical droughts in the Amazon region, Geophys. Res. Lett., 38, L12703, https://doi.org/10.1029/2011GL047436, 2011.

Marlon, J. R., Bartlein, P. J., Carcaillet, C., Gavin, D. G., Harrison, S. P., Higuera, P. E., Joos, F., Power, M. J., and Prentice, I. C.: Climate and human influences on global biomass burning over the past two millennia, Nat. Geosci., 1, 697-702, 2008.

Moran, E. F.: Deforestation and land use in the Brazilian Amazon, Hum. Ecol., 21, 1-21, https://doi.org/10.1007/BF00890069, 1993.

Morton, D. C., DeFries, R. S., Randerson, J. T., Giglio, L., Schroeder, W., and van der Werf, G. R.: Agricultural intensification increases deforestation fire activity in Amazonia, Glob. Change Biol., 14, 2262-2275, https://doi.org/10.1111/j.13652486.2008.01652.x, 2008.

Morton, D. C., DeFries, R. S., Nagol, J., Souza, C. M., Kasischke, E. S., Hurtt, G. C., and Dubayah, R.: Mapping canopy damage from understory fires in Amazon forests using annual time series of Landsat and MODIS data, Remote Sens. Environ., 115, 17061720, 2011.

Morton, D. C., Le Page, Y., DeFries, R., Collatz, G. J., and Hurtt, G. C.: Understory fire frequency and the fate of burned forests in southern Amazonia, Philos. T. Roy. Soc. B, 368, 20120163 , https://doi.org/10.1098/rstb.2012.0163, 2013.

Nepstad, D., Soares-Filho, B. S., Merry, F., Lima, A., Moutinho, P., Carter, J., Bowman, M., Cattaneo, A., Rodrigues, H., Schwartz- man, S., and McGrath, D. G.: The end of deforestation in the Brazilian Amazon, Science, 326, 1350-1351, 2009.

Nepstad, D., McGrath, D., Stickler, C., Alencar, A., Azevedo, A., Swette, B., Bezerra, T., DiGiano, M., Shimada, J., da Motta, R. S., and Armijo, E.: Slowing Amazon deforestation through public policy and interventions in beef and soy supply chains, Science, 344, 1118-1123, 2014.

Nepstad, D. C., Verssimo, A., Alencar, A., Nobre, C., Lima, E., Lefebvre, P., Schlesinger, P., Potter, C., Moutinho, P., Mendoza, E., and Cochrane, M.: Large-scale impoverishment of Amazonian forests by logging and fire, Nature, 398, 505-508, 1999.

Power, M. J., Mayle, F. E., Bartlein, P. J., Marlon, J. R., Anderson, R. S., Behling, H., Brown, K. J., Carcaillet, C., Colombaroli, D., Gavin, D. G., and Hallett, D. J.: Climatic control of the biomassburning decline in the Americas after AD 1500, Holocene, 23, 3-13, 2013.

Power, M. J., Whitney, B. S., Mayle, F. E., Neves, D. M., de Boer, E. J., and Maclean, K. S.: Fire, climate and vegetation relationships in the Bolivian Chiquitano seasonally dry tropical forest, Philos. T. R. Soc. B, 371, 20150165, 2016.

Soares-Filho, B., Rajão, R., Macedo, M., Carneiro, A., Costa, W., Coe, M., Rodrigues, H., and Alencar, A.: Cracking Brazil's forest code, Science, 344, 363-364, 2014.

van der Werf, G. R., Randerson, J. T., Giglio, L., Collatz, G. J., Mu, M., Kasibhatla, P. S., Morton, D. C., DeFries, R. S., Jin, Y., and van Leeuwen, T. T.: Global fire emissions and the contribution of deforestation, savanna, forest, agricultural, and peat fires (1997-2009), Atmos. Chem. Phys., 10, 11707-11735, https://doi.org/10.5194/acp-10-11707-2010, 2010.

van Marle, M. J. E., van der Werf, G. R., de Jeu, R. A. M., and Liu, Y. Y.: Annual South American forest loss estimates based on passive microwave remote sensing (1990-2010), Biogeosciences, 13, 609-624, https://doi.org/10.5194/bg-13-609-2016, 2016.

van Marle, M. J. E., Field, R. D., Werf, G. R., Estrada de Wagt, I. A., Houghton, R. A., Rizzo, L. V., Artaxo, P., and Tsigaridis, K.: Fire and deforestation dynamics in Amazonia (1973-2014), Global Biogeochem. Cy., 31, 24-38, 2017.

Vera, C., Higgins, W., Amador, J., Ambrizzi, T., Garreaud, R., Gochis, D., Gutzler, D., Lettenmaier, D., Marengo, J., Mechoso, C. R., and Nogues-Paegle, J.: Toward a unified view of the American monsoon systems, J. Climate, 19, 4977-5000, 2006.

Wooster, M. J., Zhukov, B., and Oertel, D.: Fire radiative energy for quantitative study of biomass burning: Derivation from the BIRD experimental satellite and comparison to MODIS fire products, Remote Sens. Environ., 86, 83-107, 2003.

World Meteorological Organization: Guide to Meteorological Instruments and Methods of Observation, 6th Edn., Secretariat of the World Meteorological Organization, Geneva, Switzerland, 1996.

Yoon, J. H. and Zeng, N.: An Atlantic influence on Amazon rainfall, Clim. Dynam., 34, 249-264, 2010.

Zhang, K., Almeida Castanho, A. D., Galbraith, D. R., Moghim, S., Levine, N. M., Bras, R. L., Coe, M. T., Costa, M. H., Malhi, Y., Longo, M., and Knox, R. G.: The fate of Amazonian ecosystems over the coming century arising from changes in climate, atmospheric $\mathrm{CO}_{2}$, and land use, Glob. Change Biol., 21, 2569-2587, 2015. 